\title{
Detecting the manipulation of earnings in the company: triangulation of methods
}

\author{
Lucia Svabova ${ }^{1, *}$ \\ ${ }^{1}$ University of Zilina, Faculty of Operation and Economics of Transport and Communications, \\ Department of Economics, Univerzitna 1, 01026 Zilina, Slovakia
}

\begin{abstract}
.
Research background: Earnings management is a current topic in the world of financial management. It can be considered as a global phenomenon of today's modern approach to the reporting of accounting information and related accounting decisions of managers, which may affect the overall results of financial statements. Many companies use earnings management as a tool to maintain stable profit growth or prevent "red numbers" from appearing in financial statements that are not beneficial to the company.

Purpose of the article: Understanding what earnings management represents and why it is performed is essential for users of a company's financial statements. However, detecting manipulation in companies is not easy, because Earnings management is successful if it is invisible. Therefore, statistical models are usually used to detect these practices. The aim of this paper is to show that the use of several methods strengthens the results obtained and is more probably to reveal possible manipulation of earnings in companies.

Methods: In this study, we used triangulation of methods to detect Earnings management in companies: one of the most frequently used model in this area, Beneish model, but also the model for Slovak companies M-score SVK, which was created under the inspiration of the Beneish model and finally, the model of the company's propensity score of manipulation.

Findings \& Value added: The study provides a global view of the possibilities of applying these three models to detect manipulation in the company. The idea of triangulation of methods is based on the consideration that if all the methods detect possible manipulation, it is very likely that it actually happens in the company.
\end{abstract}

Keywords: earnings management; earnings manipulation; discriminant model; propensity score model; Beneish model

JEL Classification: C52; D22; M41

\footnotetext{
* Corresponding author: lucia.svabova@,fpedas.uniza.sk
} 


\section{Introduction}

Earnings management is a current topic in the world of financial management. In Slovakia, however, it is not as widespread as abroad and this research area has not been elaborated in more detail, apart from some of the first studies. Nevertheless, it is a phenomenon of today's modern approach to the reporting of accounting information and the related accounting decisions of managers that may affect the overall results of financial statements. Many companies use earnings management as a tool to maintain stable profit growth or prevent "red numbers" from appearing in financial statements that are not beneficial to the companies. Understanding what earnings management represents and why it is performed is essential for users of financial statements of the companies [1-4].

The goal of every company is to make a reasonable profit. Nowadays, however, we encounter the deliberate influencing accounting information and manipulation of earnings, but the earnings management is not illegal and in most cases, what managers are doing, is within the law. Based on their judgment, they present the financial results of the company in a way that best suits their interests [5]. In [6], the authors state that earnings management is an accounting technique for financial reporting that shows a mostly positive view of corporate finances and the financial situation.

However, these facts also show that earnings management is successful when it is invisible and therefore difficult to detect and quantify. To this end, several studies and models have been developed, the main goal of which is to identify companies that implement earnings management [7,8]. In this study, we focus on the triangulation of methods, or models, that can be used to detect earnings management. The main idea of this study is that the application of three different methods will strengthen the obtained results and if these methods agree in the result, it is more likely that this phenomenon really occurs in the company. With this article, we also try to fill the scientific gap, which is still in this area of research in the Slovak Republic, where only a few first studies on this issue are published and the model for Slovak companies was created in the study [9]. The aim of this paper is to extend this study to the knowledge of other suitable methods that can be applied for the detection of earnings management in the Slovak environment.

The rest of the article is designed as follows. In the Literature review, we present studies by authors who have dealt with this issue in other countries and several of them also in Slovakia. In chapter Methods, we present the theoretical basis of three methods that we propose to apply to the detection of earnings management for Slovak companies. In the Results section, the application of these three models to a sample of companies is presented, and the results of this detection are evaluated in the Discussion.

\subsection{Literature review}

The issue of profit manipulation is currently topical and is being addressed by several analysts and economists in various countries around the world. An example is a study [10], in which the authors focused on the analysis of pension costs and cash contributions in enterprises with defined benefits. They examine whether the managers of these companies manipulate the accrual of pensions to achieve the required income. In the study, they developed an aggregate discretionary pension rate and subsequently developed a multivariate regression model for this aggregate pension income management measure to detect manipulation in pension companies. Another example is the study [11], which focused on the rounding of net income and earnings per share in German companies as a symptom of negligible "earnings cosmetics" or biased significant earnings management. They linked the analysis to the introduction of the euro in Germany and showed that rounding-up is likely the result of earnings management. The study [12] examines, whether, in Chinese listed firms and 
accounting firms, the distance between the auditor and the client affects the corporate real earnings management. The authors found that there is a positive association between real earnings management and the distance between the auditor and the client, and this is more pronounced in client companies with lower information transparency and higher business complexity. Tran et al. in their study [13] focused on the relationship between ownership structure factors and earnings management behaviour in Vietnamese commercial banks. Using the least-squares method, but also other methods, the authors created a model for identifying the earnings management in Vietnamese commercial banks. In [14], the authors focused on creativity and innovation and in companies and their impact on the occurrence of earning management and found that managers in a more innovative corporate culture tend to engage in higher levels of real earnings management. In [15], the authors applied conventional regressions as well as generalized regression neural networks to examine the relationship between corporate governance and earnings management in a sample of British and Egyptian companies. They also focused on the impact of quality management and control of corruption in companies and the occurrence of earnings management. The authors state that corruption has a very strong effect on earnings management and that controlling the level of corruption in their countries can discourage managers of the companies from earnings management. Several studies dealing with the issue of earnings management and its detection have also been published by authors from Slovakia, such as [1-4,7-9,16-20].

\section{Methods}

For the detection of earnings management, we used triangulation of methods: one of the most frequently used model in this area, Beneish model [21], the model for Slovak companies $M-$ score $_{s v k}[9]$, which was created under the inspiration of the Beneish model and finally, the model of the company's propensity score of manipulation $P-$ score $_{s v k}$ [22]. In all three of these methods, we use a set of variables, following Beneish's original approach. These variables are listed in Table 1.

Table 1. Variables used in the models

\begin{tabular}{|c|c|}
\hline Variable name & Index \\
\hline$D S R I$ & Days Sales in Receivables Index \\
\hline$G M I$ & Gross Margin Index \\
\hline$A Q I$ & Asset Quality Index \\
\hline$S G I$ & Sales Growth Index \\
\hline$D E P I$ & Depreciation Index \\
\hline$S G A I$ & Sales, General, and Administrative Expenses Index \\
\hline$L V G I$ & Leverage Index \\
\hline$T A T A$ & Total Accruals to Total Assets \\
\hline
\end{tabular}

The Beneish model is created using probit regression and indicates the tendency of companies for fraudulent accounting processes [16]. This model was created using the sample of 2,406 companies, of which 74 committed financial fraud during the years 1982 1992 and 2,332 companies that did not. The model tries to identify this behaviour in the company by calculating the value of the so-called $M$ - score according to the following model 


$$
\begin{array}{r}
M-\text { score }=-4.840+0.920 \cdot D S R I+0.528 \cdot G M I+0.404 \cdot A Q I+0.892 \cdot S G I \\
+0,115 \cdot D E P I-0.172 \cdot S G A I-0.327 \cdot L V G I+4.697 \cdot \text { TATA }
\end{array}
$$

The dividing limit of the $M-$ score is considered to be -2.22 in the Beneish model. The $M-$ score higher than -2.22 indicates that the company probably applied opportunistic earnings management and the value of $\mathrm{M}$-score lower than this limit means that the company is not suspicious of the fraudulent accounting processes. Beneish's model correctly identifies from $58 \%$ to $76 \%$ of fraudulent companies [21].

Based on the idea of the Beneish model, a model for Slovak companies was created in the study [9]. In this model, the variables listed in Table 1 are used, but in two consecutive years - the year preceding the fraudulent conduct in the company (variables are marked by lower case $b$ ) and the year in which the fraudulent conduct was detected (variables marked by lower case $t f$ ). This model is created using discriminant analysis, and the equation for calculating the so-called $M-$ score $_{s v k}$ is the following

$$
\begin{aligned}
M-\text { score }_{s v k}= & 0.29 \cdot A Q I_{b}+0.060 \cdot A Q I_{t f}-0.437 \cdot D E P I_{b}+0.180 \cdot D E P I_{t f} \\
& +0.100 \cdot D S R I_{b}+0.667 \cdot D S R I_{t f}+0.943 \cdot G M I_{b}+1.511 \\
& \cdot G M I_{t f}-1.561 \cdot L V G I_{b}-1.523 \cdot L V G I_{t f}+0.427 \cdot S G A I_{b} \\
& +0.681 \cdot S G A I_{t f}-0.051 \cdot S G I_{b}+1.920 \cdot S G I_{t f}+0.497 \\
& \cdot \text { TATA }_{b}+1.031 \cdot \text { TATA }_{t f}-3.699
\end{aligned}
$$

A positive value of the $M-$ score $_{s v k}$ means that the company probably carried out opportunistic earnings management to avoid its tax liabilities in the given year and negative values indicate no fraudulent conduct in the company.

The third model applied in this study was created based on a set of the same variables as the previous model, taking into account the variables from the original Beneish model, but in two consecutive years. This model, in addition to classifying the company into the group of suspicious from tax fraud or companies that are not suspicious, also quantifies the probability of the company's propensity to manipulate. The model is created using logistic regression and the equation for calculating the so-called propensity score $P-$ score $_{s v k}$ of the profit, manipulation is the following

$$
P-\text { score }_{s v k}=\frac{1}{(1+\exp \{z\})},
$$

where

$$
\begin{aligned}
z=49.582 A Q I_{b} & -0.162 A Q I_{t f}-4.381 D E P I_{b}+74.063 D E P I_{t f}-0.595 D S R I_{b} \\
& -51.387 D S R I_{t f}+0.883 G M I_{b}-878.919 G M I_{t f} \\
& +172.012 L V G I_{b}+123.410 L V G I_{t f}-24.118 S G A I_{b} \\
& -30.941 S G A I_{t f}+29.541 S G I_{b}-200.461 S G I_{t f}-2.998 T A T A_{b} \\
& -104.104 T A T A_{t f}
\end{aligned}
$$

The result of the application of this model is the quantification of the propensity score to the manipulation of profits, in other words, the estimation of the probability of fraudulent conduct of the company. Based on the value of the estimated probability, we can classify the company either among those that are likely to realize earnings management or among those where there is a low probability of the earnings management. Usually, a propensity score of 0.5 is used as a dividing criterion. 


\section{Results}

We applied the abovementioned three models to detect fraud in the preparation of financial statements in Slovak companies. We used a sample of 1,900 Slovak companies, from which we have empirical data from the years 2016 - 2018. To detect fraudulent company, we applied all three mentioned models: the original Beneish model for $M$-score, a discriminant model for $M-$ score $_{s v k}$ derived from this original model, and finally a model for the propensity score estimation of the probability of fraudulent conduct in the enterprise $P-$ score $_{s v k}$. With this triangulation of methods, we want to show that in companies in which the three models match in the classification of the companies, this behaviour is very likely to occur. Table 2 shows the results.

Table 2. Identification of companies by triangulation of methods

\begin{tabular}{|c|c|c|c|}
\hline & $\begin{array}{c}\text { Beneish model } \\
M-\text { score }\end{array}$ & $\begin{array}{c}\text { discriminant model } \\
M-\text { score }_{\text {svk }}\end{array}$ & $\begin{array}{c}\text { propensity score model } \\
P-\text { score }_{\text {svk }}\end{array}$ \\
\hline potential fraudulent company & $743(39.1 \%)$ & $1,049(55.2 \%)$ & $927(48.79 \%)$ \\
\hline non-fraudulent company & $1,157(60.9 \%)$ & $851(44.8 \%)$ & $973(51.2 \%)$ \\
\hline \multirow{3}{*}{ match of fraud identification } & \multicolumn{2}{|c|}{$621(32.7 \%)$} & - \\
\cline { 2 - 4 } & - & \multicolumn{3}{|c|}{$529(38.4 \%)$} \\
\cline { 2 - 4 } & $685(36.1 \%)$ & - & \\
\cline { 2 - 4 } & \multicolumn{3}{|c|}{$528(27.8 \%)$} \\
\hline
\end{tabular}

In the first part of the table, we present the numbers and percentages of the entire set of companies that the model identified as fraudulent and non-fraudulent companies. In the second part of the table, we present the numbers and frequencies of those companies that were identically identified by two or all three models as a fraudulent company. As shown in Table 2, the Beneish model agrees with the $M-$ score $_{s v k}$ model in $32.7 \%$ of enterprises, with the $P-$ score $_{s v k}$ model in $36.1 \%$ of enterprises. The Slovak $M-$ score $_{s v k}$ and $P-$ score $_{s v k}$ models match in $38.4 \%$ of companies, and finally, all three models identically identified earnings management in $27.8 \%$ of companies.

\section{Discussion}

We find the results obtained in this study, where we identified the presence of earnings management in a sample of Slovak companies using triangulation methods, very useful because the application of three models strengthens the achieved results and the identical classification of the company suggests that the earnings manipulation in the company probably actually occurs. Also, two of the three models were created especially for Slovak companies, using a real sample of data, so we consider their results to be sufficiently accurate. Similar studies by the authors have been realized in other countries, for example, the study [23] in the Federation of Bosna and Herzegovina, the study [24] in Turkey and study [25] in Italy. These authors also used the Beneish model and adapted it to the conditions of a given country by changing the coefficients in the original model, or also by omitting some variables.

The weakness of this study can be considered the fact that the Slovak models were created on a relatively small sample of companies, as it is difficult to obtain real data on companies in which fraudulent conduct has been proven in the past. In the further continuation of this study, it would be appropriate to expand this database and verify the classification abilities of the created models, but also to verify their possibilities of application on companies from another country. 
This research was financially supported by the Slovak Research and Development Agency - Grant NO. APVV-17-0546: Variant complex model of Earnings management in conditions of Slovak republic as an essential tool of the market uncertainty.

\section{References}

1. Kovalova, E., Kramarova, K., Zabojnik, S. (2019). Detection of Earnings Manipulation Using Beneish M-Score Model. In K. S. Soliman (Eds.), Proceedings of the 34th International Business Information Management Association Conference (IBIMA), 10827-10832. Norristown : IBIMA.

2. Kramarova, K., Kovalova, E., Michalkova, L. (2019). Artificial Pricing of Intragroup Transactions in Context of Earnings Management - Slovak Legal Framework. In K. S. Soliman (Eds.), Proceedings of the 34th International Business Information Management Association Conference (IBIMA), 13121-13133. Norristown : IBIMA.

3. Poradova, M., Sielekova, A., Kollar, B. (2019). Theoretical Aspects of Earnings Management Models. In K. S. Soliman (Eds.), Proceedings of the 34th International Business Information Management Association Conference (IBIMA), 13110-13120. Norristown : IBIMA.

4. Strakova, L., Adamko, P. (2019). Application of Earnings Management Models in the Slovak Republic. In K. S. Soliman (Eds.), Proceedings of the 34th International Business Information Management Association Conference (IBIMA), 13386-13398. Norristown : IBIMA.

5. Mohanram, P.S. (2003). How to manage earnings management? Accounting World.

6. Durana, P., Valaskova, K., Chlebikova, D., Krastev, V., Atanasova, I. (2020). Heads and Tails of Earnings Management: Quantitative Analysis in Emerging Countries. Risks, $8(2), 57$.

7. Kliestik, T., Valaskova, K., Nica, E., Kovacova, M., Lazaroiu, G. (2020). Advanced methods of earnings management: Monotonic trends and change-points under spotlight in the Visegrad countries. Oeconomia Copernicana, 11(2), 371-400.

8. Strakova, L. (2020). Earnings management in global background. SHS Web of Conferences, 74, 01032.

9. Svabova, L., Kramarova, K., Chutka, J., Strakova, L. (2020). Detecting earnings manipulation and fraudulent financial reporting in Slovakia. Oeconomia Copernicana, 11(3), 485-508.

10. Hsieh, S.-J., Su, Y., Chang, C.-C.A. (2020). The role of discretionary pension accruals in earnings management. Journal of Applied Accounting Research, ahead-of-print (ahead-of-print).

11. Lebert, S., Mohrmann, U., Stefani, U. (2020). Rounding up performance measures in German firms: Earnings cosmetics or earnings management on a larger scale? Journal of Business Finance \& Accounting, 1-23.

12. Li, X., Lin, Z., Luo, J. (2020). Does auditor-client distance matter to real earnings management? Evidence from China. Asia-Pacific Journal of Accounting \& Economics, 27(5), 531-557.

13. Tran, T.Q., Ly, A.H., Nguyen, D.K.N. (2020). Relationship between Ownership Structures and Earnings Management Behavior in Vietnamese Commercial Banks. The Journal of Asian Finance, Economics, and Business, 7(9), 401-407.

14. Guggenmos, R D., Stede, W.A.V. der. (2020). The Effects of Creative Culture on Real Earnings Management. Contemporary Accounting Research. 
15. Abdou, H.A., Ellelly, N.N., Elamer, A.A., Hussainey, K., Yazdifar, H. (2020). Corporate governance and earnings management nexus: Evidence from the UK and Egypt using neural networks. International Journal of Finance \& Economics, forthcoming article.

16. Kramarova, K., Valaskova, K. (2020). Application of cohosen fraudulent detection technique in the Slovak business environment. SHS Web of Conferences, 74, 01019.

17. Michalkova, L., Frajtova Michalikova, K. (2020). Is the Value of the New Business Tax Shield Lower? Comparative Study of International Valuation Methods. SHS Web of Conferences, 74, 01022.

18. Siekelova, A., Podhorska, I. (2020). Earnings Indicators under the Condition of Globalization. SHS Web of Conferences, 74, 01031.

19. Svabova, L., Valaskova, K., Durana, P., Kliestik, T. (2020). Dependency analysis between various profit measures and corporate total assets for Visegrad group's business entities. Organizacija, 53(1), 80-90.

20. Valaskova, K., Durana, P. (2020). Global context of disparities in earnings management among enterprises: Evidence from Slovakia. SHS Web of Conferences, 74, 01034.

21. Beneish, M.D. (1999). The detection of earnings manipulation. Financial Analysts Journal, 55(5), 24-36.

22. Svabova, L., Kramarova, K. (n.d.). Application of counterfactual approach in the evaluation of earnings management in the company. forthcoming article.

23. Halilbegovic, S., Celebic, N., Cero, E., Buljubasic, E., Mekic, A. (2020). Application of Beneish M-score model on small and medium enterprises in Federation of Bosnia and Herzegovina. Eastern Journal of European Studies, 11(1), 146-163.

24. Ozcan, A. (2018). The use of Beneish model in forensic accounting: Evidence from Turkey. Journal of Applied Economics and Business Research, 8(1), 57-67.

25. Giunta, F., Bini, L., Dainelli, F. (2014). Verifica della base informativa per l'analisi di bilancio: Le azioni di manipolazione contabile. Controllo di Gestione, 2, 5-17. 